\title{
The effect of intravenous nitroglycerine on the treatment of high blood pressure in the emergency department
}

\author{
Ekrem Hasani*, Mimoza Lezha \\ University Hospital Centre "Mother Tereza", Tirana, Albania
}

Objectives: Hypertension is a common medical problem in the world. Rapid control of blood pressure (BP) is sometimes needed in the emergency department (ED), in order to avoid end-organ damage including ischemia to the central nervous system, the heart, or the kidneys. Aim: To study the effect of nitroglycerin iv for the treatment of high BP.

Patients and Methods: 64 patients with mean age 51.68 \pm 9.62 with high BP (systolic BP191.48 $\pm 9.33 \mathrm{mmHg}$ and diastolic BP $97.97 \pm 1.01 \mathrm{mmHg}$ ) without signs of end-organ damage, contraindications for the drug were enrolled in this prospective, single blind study. $47 \%$ of them were presented with chest pain, but without signs of myocardial ischemia. They were selected to be treated with nitroglycerin iv $5 \mathrm{mg} / 5 \mathrm{ml}$ starting with $5 \mathrm{mcg} / \mathrm{min}$ infusion initially, increased by $5 \mathrm{mcg} / \mathrm{min}$ every 3 to 5 minutes as needed up to 20 $\mathrm{mcg} / \mathrm{min}$. Electrocardiographic recordings and biochemical balance were obtained during and after the treatment. Echocardiographic examination was performed after the treatment. Checkup of BP was made after $5^{\prime}, 10^{\prime}, 15^{\prime}, 30^{\prime}, 1 \mathrm{~h}, 2 \mathrm{~h}$, $4 \mathrm{~h}$, and $6 \mathrm{~h}$ after the treatment, time which was awarded as sufficient for lowering blood pressure $\leq 140 / 90 \mathrm{mmHg}$. Side effects were assessed also.

Results: The significant lowering systolic blood pressure (SBP) and diastolic blood pressure (DBP) was noted after the first $5 \mathrm{~min}$ of the treatment (SBP $175.16 \pm 4.34$ vs 191.48 $\pm 9.33 \mathrm{mmHg}, p<0.001$ and DBP $92.03 \pm 5.97$ vs $97.97 \pm 1.01$
$\mathrm{mmHg}, \mathrm{p}<0.001)$. After $20^{\prime}$ of the treatment SBP was 136.59 $\pm 7.46 \mathrm{mmHg}, \quad p<0.001$, after $1 \mathrm{~h} 129.09 \pm 7.41 \mathrm{mmHg}$, $\mathrm{p}<0.001$ and DBP after $10^{\prime}$ of the treatment was reduced in $88.28 \pm 6.89 \mathrm{mmHg}, p<0.001$. After 20' DBP was $82.70 \pm 7.10$ $\mathrm{mmHg}, \mathrm{p}<0.001$ and after $2 \mathrm{~h} 80.00 \pm 5.62 \mathrm{mmHg}, \mathrm{p}<0.001$. The mean used dose of nitroglycerine iv was $8 \mathrm{mcg} / \mathrm{min}$. No side effects were noted during the treatment.

Conclusions: The nitroglycerine iv infusion is a safe and very effective drug for the treatment of high BP in the emergency department.

KEYWORDS: hypertension, nitroglycerin, antihypertensive drug.

CITATION: Cardiol Croat. 2013;8(9):321.

\section{Received: $3^{\text {rd }}$ Aug 2013}

*Address for correspondence: Department of Cardiology, University Hospital Center "Mother Tereza" Rr. Dibres 370, city code 1000, Tirana, Albania.

Phone: +355682140304

E-mail: mlezha@hotmail.com

\section{Literature}

1. Decker WW, Godwin SA, Hess EP, Lenamond CC, Jagoda AS; American College of Emergency Physicians Clinical Policies Subcommittee (Writing Committee) on Asymptomatic Hypertension in the ED. Clinical policy: critical issues in the evaluation and management of adult patients with asymptomatic hypertension in the emergency department. Ann Emerg Med. 2006;47:237-49. 